Pobrane z czasopisma Annales I - Philosophy and Sociology http://philosophia.annales.umcs.pl Data: 26/04/2023 13:39:07

10.1515/sectio-2015-0027

A N N A L E S

UNIVERSITATIS MARIAE CURIE-SKŁODOWSKA

LUBLIN - POLONIA

VOL. XL, 2

SECTIO I

2015

MICHAŁ NOWAKOWSKI

Uniwersytet Marii Curie Skłodowskiej

\title{
Zmedykalizowana psychiatria jako przykład ,geokultury”? Propozycja zastosowania analizy systemów-światów Immanuela Wallersteina w krytycznej socjologii medycyny
}

The Medicalised Psychiatry as an Example of the "Geoculture"?

The Proposition of Use of Immanuel Wallerstein's World-System Analysis in the Critical Sociology of Medicine

\section{WPROWADZENIE}

Teoria systemów-światów Immanuela Wallersteina może z powodzeniem być stosowana $\mathrm{w}$ międzynarodowych badaniach porównawczych oraz obszarze zdrowia, choroby i medycyny. Można ją (wraz z teoriami zależności) potraktować jako podłoże teoretyczne dla politycznej ekonomiki zdrowia rozumianej jako forma krytycznej makroanalizy rozprzestrzeniania się chorób i rozmieszczania usług zdrowotnych w warunkach zróżnicowanych systemów ochrony zdrowia ze szczególnym naciskiem na nierówne relacje społeczne, polityczne i ekonomiczne W ramach światowego systemu ekonomicznego ${ }^{1}$. W takim ujęciu chodzi przede wszystkim o przedstawianie globalnych nierówności zdrowotnych jako skutku ekonomicznego niedorozwoju państw zależnych/peryferyjnych. Ich podrzędna pozycja jest immanentną cechą systemu opartego na silnie nierównoważnych relacjach handlowych peryferiów z rdzeniem kapitalistycznego systemu-świata. Wynika z tego, że pierwotne wobec nierówności zdrowotnych są nierówności ekonomiczne. Interesy kapitału, którego ojczyzną są kraje centralne, stoją wyżej niż dobro społeczne w krajach peryferyjnych, często niedemokratycznych, skorumpowanych, w których łatwo jest skłonić do współpracy lokalne elity ponad

1 Zob. Morgan, 1987, za: A. Mohyuddin [et al.], World System Analysis of Biomedical Hegemony, "Advances in Anthropology" 2014, No. 4, s. 61. 
głowami niewyedukowanych, niedoinformowanych czy zastraszanych społeczeństw. Przykładem takiej analizy jest artykuł z 1989 r. autorstwa Charlesa W. Hunta, który wykorzystał teorię systemu-świata, by wytłumaczyć sposób rozprzestrzeniania się epidemii AIDS w Afryce. Zgodnie z przyjętą perspektywą teoretyczną kraje afrykańskie jako obszary peryferyjne są eksploatowane przez korporacje krajów centrum, których inwestycje nie służą ekonomicznemu rozwojowi, lecz eksploatacji rzadkich zasobów. W celu maksymalizacji zysków kapitał lokuje swoje inwestycje nierównomiernie, nie licząc się z potrzebami lokalnych rynków pracy, przez co w chaotyczny sposób tworzą się ogromne metropolie przyciągające pracowników (przede wszystkim mężczyzn) z dużych, nierozwiniętych obszarów wiejskich. Niedobór miejsc pracy dla kobiet skutkuje długotrwałą separacją mężczyzn od swoich rodzin, które zostają na wsi i opiekują się gospodarstwem rolnym. Oddzielenie od najbliższych niszczy tradycyjne wzorce życia rodzinnego i seksualnego. W nowych ośrodkach przemysłowych pojawia się duży popyt na prostytucję, co w konsekwencji zasadniczo przyczynia się do wybuchów epidemii chorób wenerycznych i HIV. Hunt zwraca uwagę, że zarażeni mężczyźni z powodu złego stanu zdrowia są zwalniani i wracają do domów rodzinnych, po czym zarażają wirusem swoje żony. Zdarza się również, że zmuszone sytuacją ekonomiczną, wyjeżdżają one do miasta, gdzie z dużym prawdopodobieństwem mogą trafić do sektora usług seksualnych, gdzie szybko infekowane są wirusem² ${ }^{2}$. Negatywne skutki społeczne i ekonomiczne dominacji zagranicznego kapitału w państwach peryferyjnych pogłębiają dysfunkcjonalność systemów ochrony zdrowia, zabezpieczeń społecznych czy ochrony środowiska. Z punktu widzenia korporacji budowa instytucji państwa dobrobytu w krajach peryferyjnych, oględnie mówiąc, nie jest priorytetem, gdyż liczy się przede wszystkim koszt pracy, a ten jest najniższy w krajach biednych, pozbawionych społeczeństwa obywatelskiego. $Z$ tego względu w krajach peryferyjnych zgodne z interesem zagranicznego kapitału jest utrzymywanie status quo przez współpracę i wspieranie autorytarnych, kleptokratycznych reżimów będących gwarantem neoliberalnych porządków. Podsumowując, strukturę zachorowalności i umieralności w poszczególnych krajach/ regionach można odnieść do pozycji danego kraju na mapie globalnego systemuświata ${ }^{3}$. Peryferyjność negatywnie wpływa na poziom zdrowia populacji zarówno

2 C.W. Hunt, Migrant Labor and Sexually Trasnmitted Disease: AIDS in Africa, "Journal of Health and Social Behavior" 1989, Vol. 30, No. 4, DOI: http://dx.doi.org/10.2307/2136985.

3 Z zasadnością takiego podejścia zgadzają się Martin Hyde i Anthony Rosie, którzy w tekście World Systems Theory and the Epidemiological Transition zestawili teorię systemu-świata Wallersteina z teorią przejścia epidemiologicznego, twierdząc, że może to wspomóc rozwój obu tych koncepcji. Po pierwsze, uważają oni, że analizy dotyczące zdrowia populacji, szczególnie dzietności i umieralności, stanowią ważny składnik oceny poziomu nierówności pomiędzy krajami, a celem teorii systemu świata jest wyjaśnianie takich różnic. Po drugie, według autorów teoria przejścia epidemiologicznego charakteryzuje się zbyt „państwo-centryczną” perspektywą, a z kolei teoria 
przez działania zagranicznego kapitału nieliczącego się z dobrem społecznym, jak i słabość instytucji państwowych (niebędących dostatecznie zdolnymi i zmotywowanymi do prowadzenia sensownej polityki zdrowotnej), która jest funkcjonalna z punktu widzenia kapitalistycznego systemu-świata.

Teoria kapitalistycznego systemu-świata może również być wykorzystana do interpretacji globalnego sukcesu zachodniej biomedycyny. Tematem tym zajmują się od dawna krytyczni antropologowie medycyny, którzy widzieli w niej narzędzie kulturowego imperializmu, który jest paralelnym i wspierającym procesem dla imperializmu politycznego i ekonomicznego ${ }^{4}$. Funkcją biomedycyny jest według nich wspieranie komercjalizującej się branży ochrony zdrowia, ale też legitymizacja neoliberalnego systemu przez marginalizowanie społeczno-ekonomicznych determinantów nierówności zdrowotnych. Twierdzą tak m.in. Berliner (1982) i Kelman (1975): , ,...] kapitalizm i biomedycyna nawzajem się wspierają przez swoje konstrukty ideologiczne oraz dzielą te same cele, wytwarzając niepewność wokół socjoekonomicznych powodów zapóźnienia zdrowotnego i ekonomicznego"s. W ten sposób biomedycyna pomaga „wypchnąc" ze sfery polityki szereg problemów społecznych będących konsekwencjami przyjętego modelu ekonomicznego przez przekształcenie ich w indywidualne problemy zdrowotne. Krytyczni antropologowie medycyny, badając te zjawiska, koncentrowali się na imperializmie zachodniej biomedycyny w krajach Trzeciego Świata, która miała polegać na wypieraniu lokal-

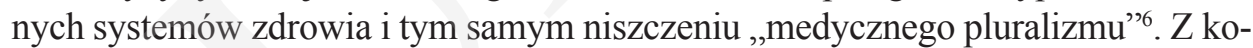
lei w niniejszym artykule na przykładzie psychiatrii chciałbym pokazać, jak biomedycyna (w postaci zmedykalizowanej psychiatrii) wypiera inny „zachodni” system wiedzy, czyli psychoanalizę, i inne podejścia opierające się na psychoterapiach. Celem artykułu jest próba użycia teorii i aparatu pojęciowego Immanuela Wallersteina do opisania polityczno-ekonomicznej funkcji współczesnej, zorientowanej biologicznie psychiatrii. Zmedykalizowany paradygmat chorób psychicznych, dominujący w amerykańskiej psychiatrii, można potraktować jako część „,geokultury” eksportowanej z centrum do peryferii „kapitalistycznego systemu-świata”, definiowanego przez Wallersteina jako normy i modele dyskursu, które „w obrębie systemu-świata są szeroko akceptowane jako prawomocne" ". Celem owej „geokultury"

\footnotetext{
systemu światowego może zaoferować spojrzenie szersze. Pozwala ona wyjaśniać poziom zdrowia w danej populacji za pomocą czynników wynikających z przynależności danego kraju do centrum, semi-peryferii bądź peryferii systemu światowego. Zob. M. Hyde, A. Rosie, World Systems Theory and the Epidemiological Transition, [w:] Contemporary Theorists for Medical Sociology, ed. G. Scambler, Abington, Oxon 2012.

4 Elling, 1981, za: H.A. Baer, M. Singer, I. Susser, Medical Anthropology and the World System, $2^{\text {nd }}$ ed., Westport 2003, s. 40.

5 Za: A. Mohyuddin [et al.], op. cit., s. 61.

6 H.A. Baer, M. Singer, I. Susser, op. cit., s. 41.

7 I. Wallerstein, Analiza systemów-światów. Wprowadzenie, Warszawa 2007, s. 132.
} 
jest wytwarzanie dyskursu i norm dotyczących definiowania, etiologii i sposobów radzenia sobie z problemami emocjonalnymi, stresem i zaburzeniami psychicznymi w taki sposób, by jednostka poszukiwała w sobie winy za zachorowanie oraz traktowała zaburzenia psychiczne jako zjawisko o biologicznej etiologii, którego leczenie w zasadzie powinno opierać się na farmakoterapii. Co więcej, zmedykalizowana psychiatria ma się przyczyniać do utrwalania przewagi gospodarek państw rdzenia kapitalistycznego systemu-świata w obszarze ochrony zdrowia psychicznego, ponieważ narzuca taką etiologię problemów psychicznych, która premiuje terapie (często przez lata chronione patentami) będące w posiadaniu zachodnich koncernów farmaceutycznych.

\section{ŚWIATOWA HEGEMONIA AMERYKAŃSKIEJ KLASYFIKACJI CHORÓB PSYCHICZNYCH}

W kwietniu 2013 r. w czasopiśmie „Psychiatric Times” amerykański psychiatra pochodzący z Iranu, Nassir Ghaemi, opublikował tekst zatytułowany List do psychiatry cudzoziemca. Przyjmując perspektywę outsidera, stwierdza w nim:

[...] na świecie istnieje jedna wielka potęga - Ameryka. Kraj ten nie jest jedynie potęgą militarną, ale również kulturową. W psychiatrii zagarnęła ona prawie wszystkie kraje co najmniej tak samo skutecznie, jak jej siły polityczne pokonały sowiecki komunizm. [...] Cała psychiatria, gdziekolwiek na świecie, to psychiatria amerykańska ${ }^{8}$.

Zdaniem autora głównym źródłem tej dominacji jest klasyfikacja zaburzeń psychicznych Amerykańskiego Towarzystwa Psychiatrycznego (DSM - Diagnostic and Statistical Manual of Mental Disorders) $)^{9}$. Jak stwierdza dalej, „kiedy Związek Radziecki upadał, DSM się rozrastał: polityczny tryumf Ameryki został przeniesiony na wszystkie poziomy, w tym medycynę i psychiatrię"10. Rzeczywiście, trzecia edycja DSM, opublikowana w 1980 r., przyczyniła się do gruntownej zmiany amerykańskiej psychiatrii, a po upadku Bloku Wschodniego stała się najważniejszym źródłem wiedzy o zaburzeniach psychicznych na całym świecie. Potwierdzeniem dominacji amerykańskiej psychiatrii także w Polsce jest opublikowany w 2011 r. w czasopiśmie „Psychiatria Polska” artykuł, którego autorzy opisują koncepcyjne założenia opracowywanej klasyfikacji zaburzeń psychicznych w ramach międzynarodowej klasyfikacji chorób ICD-11 (International Classification of Diseases). Szczególnie istotny jest następujący fragment:

8 N. Ghaemi, Letter to a Foreign Psychiatrist, "Psychiatric Times" 2013, www.psychiatrictimes.com/letter-foreign-psychiatrist [dostęp: 05.12.2013].

9 Diagnostic and Statistical Manual of Mental Disorders, $3^{\text {rd }}$ ed., Washington 1980.

10 N. Ghaemi, op. cit. 
W oparciu o wyniki ważone, w oparciu o deklarację osobistego stosowania w codziennej pracy klinicznej, ustalono realne światowe wykorzystanie wiodących klasyfikacji psychiatrycznych. Dwie najpopularniejsze to: ICD-10 (63,9\% deklaracji) i DSM-IV (29,9\%), lokalne (5,2\%), ICD-8 i ICD-9 (1\%). Ponieważ kształt ICD-10 jest w znacznej mierze wynikiem wzorowania się na rodzinie klasyfikacji amerykańskich (DSM-III, DSM-III-R, DSM-IV), można mówić o udanym, twórczym przekształceniu. Planowany czas oficjalnych edycji DSM-5 (2013) i ICD-11 (2015) każe przypuszczać, że podobne odwzorowanie nastąpi ponownie ${ }^{11}$.

W dalszej części tekstu znajduje się jeszcze bardziej znamienny fragment:

W przeciwieństwie do opisu zaburzeń psychicznych w ICD-9, ICD-10 zaoferowało lekarzom system nowoczesny, wszechstronny i praktyczny, wzorowany na dojrzałych, rozwijanych od dziesięcioleci rozwiązaniach systemu amerykańskiego (DSM). Nie ma więc potrzeby rewolucji w odniesieniu do ICD-11. Można oczekiwać ewolucyjnego dostosowania klasyfikacji do postępów medycyny, jak również harmonizacji z nową wersją DSM-5 $5^{12}$.

Mimo że w wymienionym artykule opisywana jest demokratyczna procedura konstruowania klasyfikacji międzynarodowej (nawet z możliwością konstruowania klasyfikacji narodowych uwzględniających specyfiki lokalne), rzuca się w oczy fakt, iż autorzy artykułu jako niepodważalną uznają wyższość klasyfikacji amerykańskiej, do której należy upodobnić ICD-11. I rzeczywiście, jeszcze do lat 90. XX w. amerykańska klasyfikacja konkurowała z wydawaną w Genewie klasyfikacją Światowej Organizacji Zdrowia ICD, która była bardziej przychylnie usposobiona do psychoanalityków i była bardziej podejrzliwa w stosunku do niejasnych opisów. Jednak od opublikowania DSM IV w 1994 r. klasyfikacja WHO straciła swoją specyfikę, a amerykański sposób klasyfikowania zaburzeń psychicznych, tworzony przez biologicznie zorientowanych neuropsychiatrów, zyskał globalny zasięg i zaczął kształtować sposób, w jaki świat myśli o zaburzeniach psychicznych ${ }^{13}$.

Odnosząc się do sytuacji w Polsce, psychiatra Bogdan de Barbaro ocenia, iż na „na poziomie teoretycznym przyjmuje się, że niezbędne jest otwarcie zarówno na przyrodoznawczy, jak i na humanistyczny wymiar psychiatrii”, co - jak zauważa - postulowane jest na kartach podręczników psychiatrii ${ }^{14}$. Jednak według niego

[...] w praktyce niezwykle rzadko udaje się te perspektywy łączyć. Psychiatra na ogół - niezależnie od „poprawnych politycznie” deklaracji o swym podejściu holistycznym („,złowiek jest całością”) czy integracyjnym (,należy łączyć farmakoterapię z psychoterapią”) - w praktyce przyjmuje jako dominującą jedną z narracji i, koncentrując się na biologicznym wymiarze pacjenta, staje

11 J. Heitzman, B. Łoza, W. Kosmowski, Klasyfikacja zaburzeń psychicznych - koncepcyjne założenia ICD-11, „Psychiatria Polska” 2011, Vol. XLV, nr 6, s. 944.

12 Ibidem, s. 949-950.

13 C. Lane, Shyness. How Normal Behavior Became a Sickness, New Haven \& London 2007, s. 3.

14 B. de Barbaro, Tożsamość psychiatrii?, „Postępy Psychiatrii i Neurologii” 2010, Vol. 19, nr 4, s. 343. 
się „,specjalistą od mózgu i jego patologii” albo zajmując się wymiarem psychologicznym, staje się „specjalistą od umysłu i jego patologii”"15.

Zdaniem de Barbaro trudność połączenia obu perspektyw wynika z faktu, iż są to zarazem odrębne dyskursy, $\mathrm{z}$ odmiennymi metodami badawczymi, skupiające odmienne środowiska naukowe, wydające inne czasopisma i organizujące odrębne kongresy. Podział taki niewątpliwie istnieje, jednak istotnym pytaniem jest, która z tych perspektyw dominuje. Według Włodzimierza Brodniaka, mimo ogromnego rozwoju psychofarmakologii i badań biomolekularnych w latach 90., metody psychospołeczne nie są zagrożone. Jednakże

[...] zjawiska globalizacji i konwergencji, jak w każdej dziedzinie, wpływają także na stan polskiej psychiatrii, ale jak zawsze z pewnym opóźnieniem i nie z taką intensywnością, jak ma to miejsce w USA. Niemniej proces ten występuje również w Polsce, a jego implikacje medyczne i społeczne powinny być tematem poważnej dyskusji. [...] Można podsumować, że przynajmniej w sensie organizacyjnym w psychiatrii polskiej mamy do czynienia z równowagą między modelem medycznym i psychospołecznym. W leczeniu przeważa model biologiczny, a w rehabilitacji oraz działaniach w zakresie prewencji i promocji zdrowia psychicznego - model psychospołeczny ${ }^{16}$.

Skąd może wynikać owa dominacja? Najbardziej narzucające się i oczywiste wyjaśnienie to wysoka pozycja amerykańskiej nauki, wynikająca z jej poziomu merytorycznego, co jest głównie efektem większych możliwości finansowych, przyciągających najlepszych badaczy z całego świata (sytuacja ta odnosi się również do medycyny). Przyglądając się jednak omawianej dyscyplinie, jako bezpośrednią przyczynę wyżej zdiagnozowanej dominacji należy wskazać rewolucję w amerykańskiej psychiatrii, która pierwsza ,jako dyscyplina wyciągnęła się z bagna psychoanalizy" ${ }^{17}$ i skierowała się w stronę modelu medycznego oraz biologicznego podłoża chorób psychicznych i rozbudowanej nozologii w duchu nauk Emila Kraepelina. Ekspansja amerykańskiej psychiatrii wiąże się zatem z nieuniknionym wypieraniem innych modeli leczenia zaburzeń psychicznych. Ghaemi unaocznia to zjawisko, wspominając swoją wizytę w Kanadzie:

Pojechałem do Quebecu około dziesięć lat temu. Starsi francuskojęzyczni psychiatrzy grzecznie wysłuchali swojego „amerykańskiego” gościa, a potem jeden z nich w prywatnej rozmowie stwierdził: „Młody człowieku” powiedział, „tutejsi zwykli czytać klasycznych francuskich myślicieli: Pinela, Morela, Esquirola. Czytali podręcznik do psychopatologii Henri Eya. Teraz czytają jedynie DSM. Podręcznik Eya liczył 700 stron, natomiast główne choroby w DSM zajmą 70". Potrząsnął głową z niesmakiem ${ }^{18}$.

15 Ibidem, s. 343.

16 W.A. Brodniak, Czy psychiatrom jest potrzebna socjologia zaburzeń psychicznych?, [w:] W strone socjologii zdrowia, red. W. Piątkowski, A. Titkow, Lublin 2002, s. 238-239.

17 E. Shorter, Before Prozac: the Troubled History of Mood Disorders in Psychiatry, New York 2009, s. vii.

18 N. Ghaemi, op. cit. 
Pobrane z czasopisma Annales I - Philosophy and Sociology http://philosophia.annales.umcs.pl Data: 26/04/2023 13:39:07

Zmedykalizowana psychiatria jako przykład ,geokultury”?...

Cytat ten wskazuje również na może istotniejszą rzecz niż samo zjawisko rosnącej dominacji amerykańskiej psychiatrii: niezadowolenie kanadyjskiego psychiatry wynika $\mathrm{z}$ faktu, iż postrzega on owe zmiany jako rodzaj regresu, zaniedbania innych perspektyw teoretycznych i tradycji terapeutycznych w tej dyscyplinie. Na czym polega ten regres i zubożenie? Głównym zarzutem formułowanym przez krytyków współczesnej psychiatrii jest charakterystyczny dla niej biologiczny redukcjonizm, który polega na medykalizacji zaburzeń psychicznych - sprowadzaniu ich do podkategorii chorób organicznych, koncentrowaniu się na funkcjonowaniu mózgu i zaniedbywaniu umysłu, poleganiu prawie wyłącznie na lekach, przy jednoczesnej niechęci wobec psychoterapii. Co więcej, jak się okaże, owego paradygmatu nie uprawomocniają wyniki badań naukowych. Psychiatrzy nie posiadają dowodów na organiczną etiologię zaburzeń psychicznych. Zarysowana krytyka nie stanowi obecnie jednak żadnego zagrożenia dla wciąż umacniającej się psychiatrii hołdującej paradygmatowi o biochemicznej etiologii zaburzeń psychicznych. Dalsze części artykułu wyjaśnią przyczyny tego fenomenu.

\section{BODZIEC DO ZMIANY: KRYZYS POWOJENNEJ PSYCHIATRII W USA}

W pierwszej połowie XX w. w praktyce psychiatrycznej nie przywiązywano dużej wagi do pojedynczych kategorii diagnostycznych. Pierwsze oficjalne podręczniki (DSM-I z 1952 r. oraz DSM-II z 1968 r.) Amerykańskiego Towarzystwa Psychiatrycznego reprezentowały perspektywę psychodynamiczną, a szczegółowe jednostki diagnostyczne nie odgrywały w nich ważnej roli. Według tej koncepcji różnorakie symptomy nie ujawniały konkretnych jednostek chorobowych, ale były odbiciem leżących głębiej, często nieuświadamianych konfliktów wewnętrznych i zewnętrznych. Zakładano, że symptomy stanowią symboliczne objawy, które mogą być zrozumiane jedynie wtedy, kiedy zostanie przeanalizowana biografia konkretnej jednostki. Według zwolenników psychodynamiki wyodrębnianie dyskretnych zaburzeń wraz ze swoim unikalnym zestawem objawów jest niepoprawne. Wszelkie zaburzenia psychiczne według tej koncepcji można zredukować do podstawowego psychospołecznego procesu polegającego na błędnym przystosowaniu się jednostki do swojego otoczenia. Takie błędne przystosowanie może przyjąć różne formy: od mniej poważnej (neurozy) do bardzo poważnej (psychozy). Nie można określić zatem dyskretnych zaburzeń psychicznych, gdyż sam ten proces nie ma charakteru skokowego ${ }^{19}$.

Dla psychiatrii lata 70. XX w. w USA były bardzo trudne. Dominująca perspektywa teoretyczna (psychoanaliza) i dominujące leczenie zaburzeń psychicz-

19 R. Mayes, A.V. Horwitz, DSM-III and the Revolution in the Classification of Mental Illness, "Journal of the History of the Behavioral Sciences" 2005, Vol. 41(3), DOI: http://dx.doi.org/10.1002/ jhbs.20103, s. 249-250. 
nych (psychoterapia) stały się obiektem silnej krytyki ze strony anty-psychiatrów, takich jak Liang, Cooper oraz Szasz $^{20}$, a także behawiorystów utrzymujących, że każde zachowanie, w tym psychopatologia, jest rezultatem normalnego procesu uczenia się, przez co zaburzenia psychiczne nie istnieją $\mathrm{w}$ sensie medycznym ${ }^{21}$. Amerykańska psychiatria $\mathrm{w}$ tamtym okresie również przeżywała poważny kryzys, między innymi z powodu skandali, które nadszarpnęły jej reputację. Wysuwane wobec niej zarzuty to: imperialistyczne zapędy, za duża subiektywność, nienaukowość charakteryzująca się nieuzasadnionym przekonaniem, że jest w stanie wyjaśniać i leczyć choroby psychiczne. Najgłośniejszy skandal wybuchł po opublikowaniu w „Science” wyników słynnego eksperymentu Rosenhana ${ }^{22}$. Reputację psychiatrii osłabiała także zażarta wojna pomiędzy psychoanalitykami a neuropsychiatrami, wynikająca $\mathrm{z}$ fundamentalnych różnic dotyczących przyjętych metod i filozofii ${ }^{23}$. Niezadowolenie $\mathrm{z}$ funkcjonowania psychiatrii wyrażały ponadto firmy ubezpieczeniowe, którym nie podobał się brak finansowej odpowiedzialności i klinicznie potwierdzonej efektywności. W latach 60 . wiele ubezpieczeń zaczęło także uwzględniać częściowe pokrywanie kosztów psychoterapii, a w latach 70. tę funkcję zaczął pełnić również federalny program „Medicaid”. Pieniądze przestały zatem być wewnętrzną sprawą pomiędzy psychiatrą a pacjentem. „Zdrowie” i „patologia”, rozumiane w psychiatrii dynamicznej jako krańce kontinuum, nie odpowiadały logice funkcjonowania ubezpieczycieli zdrowotnych, którzy chcieli płacić za leczenie konkretnych chorób, którego efektywność miałaby być też możliwa do oceny. Firmy ubezpieczeniowe widziały w psychoanalizie „worek bez dna”, wymagający potencjalnie nieskończonych zasobów na leczenie, które często trwało latami. Zarówno więc prywatne, jak i publiczne instytucje płacące za terapie wywierały presję do podjęcia zmian ${ }^{24}$.

Krytyce poddawano także preferowanie przez psychiatrów stosowania terapii wobec ludzi, którzy borykali się z różnymi problemami życiowymi, ale nie byli „obiektywnie chorzy psychicznie”. Brak wyraźnej granicy między zdrowiem a chorobą psychiczną powoduje, że w zasadzie każdego można w pewnym momencie życia, w jakimś stopniu, uznać za chorego. Jak stwierdzają Mayez i Horwitz ${ }^{25}$, pomiędzy 1900 a 1970 r. psychoanaliza oprócz leczenia neuroz zajęła się bardziej ogólnymi, nieakceptowanymi wzorami przystosowawczymi, charakte-

20 Więcej o anty-psychiatrii zob. M. Nowakowski, Krytycy współczesnej medycyny. Proces medykalizacji w perspektywie nauk społecznych, [w:] Lekarz - historia i wyzwania zawodu, red. E. Anczyk, Sosnowiec 2010, s. 137-140.

21 A.V. Horwitz, J.C. Wakefield, The Medicalization of Sadness: How Psychiatry Transformed a Natural Emotion into a Mental Disorder, "Salute e Società" 2009, Vol. VIII, No. 2, s. 57.

22 D.L. Rosenhan, Being Sane in Insane Places, "Science" 1973, No. 179(4070).

23 C. Lane, op. cit., s. 39-42.

24 R. Mayes, A.V. Horwitz, op. cit., s. 253.

25 Ibidem, s. 250. 
rem czy problemami osobistymi. Kirk i Kutchins wyjaśniają, że psychoterapeuci preferowali klientów, którzy byli młodzi, atrakcyjni, komunikatywni, inteligentni i zamożni, zaniedbując bardziej potrzebujących ${ }^{26}$. Skupianie się na takiej klienteli raziło, zwłaszcza w okresie gwałtownej deinstytucjonalizacji leczenia pacjentów psychiatrycznych. Polegała ona na zwalnianiu ze szpitali psychiatrycznych pacjentów przebywających tam przez długi czas. Deinstytucjonalizacja psychiatrii była reakcją na krytykę i miała przestać się kojarzyć ze szpitalami psychiatrycznymi, w których pacjenci byli izolowani nawet na wiele lat. Jednym z czynników, które wspomagały ten proces było odkrycie i wprowadzenie do obiegu antypsychotycznego leku o nazwie chlorpromazyna, dzięki któremu możliwe stało się uspokajanie pobudzonych pacjentów i kontrola najbardziej poważnych symptomów psychoz, dzięki czemu - przynajmniej w teorii - mogli oni funkcjonować w społeczeństwie ${ }^{27}$. Skutkiem tego procesu było powstanie kategorii chorych psychicznie krążących pomiędzy instytucjami opieki zdrowotnej, często mających kłopoty z prawem oraz nadużywających alkoholu i narkotyków. Dla psychiatrówpsychoanalityków tacy pacjenci (np. schizofrenicy albo narkomani) byli nieatrakcyjni i frustrujący ze względu na napotykane podczas leczenia trudności. Z tego względu często odsyłali ich do psychologów lub pracowników społecznych ${ }^{28}$.

Ze względu na fakt, że większość zwolnionych ze szpitali pacjentów nie reagowało na psychoanalizę i psychoterapię, stosowanie leków jako terapii stało się coraz powszechniejsze, a pod koniec lat 70. psychiatra nieprzepisujący leków był już raczej wyjątkiem. Zatem nowy, pozaszpitalny, oparty na farmakoterapii model leczenia zaburzeń psychicznych stawał się coraz bardziej popularny jeszcze przed publikacją klasyfikacji DSM-III (1980). Opierające się na obserwowalnych symptomach zaburzenia psychiczne, które pojawiły się w nowej edycji klasyfikacji DSM, wspomogły proces zwiększania się roli farmakoterapii w psychiatrii. Natomiast psychoanaliza była coraz bardziej marginalizowana z powodu niemożności zaspokojenia rosnących potrzeb leczenia osób poważnie chorych psychicznie w warunkach pozaszpitalnych. Nie była też w stanie wyodrębnić konkretnych jednostek diagnostycznych, które ułatwiłyby sprzedaż leków ${ }^{29}$.

Zagrożeniem, które zdaniem Moyesa i Horwitza zmobilizowało psychiatrów do zmian, była rosnąca konkurencja w świadczeniu usług psychoterapeutycznych

26 Kirk, Kutchins, 1992, s. 19, za: R. Mayes, A.V. Horwitz, op. cit., s. 254.

27 Mayes i Horwitz (op. cit., s. 254-255) przytaczają dane dotyczące zmniejszającej się liczby pacjentów w szpitalach psychiatrycznych. W 1955 r. było ich 559 tys., a dekadę później - 475 tys., czyli o $15 \%$ mniej. Kiedy zaczęto stosować chlorpromazynę i walczyć o prawa obywatelskie chorych psychicznie, a państwo wprowadziło nową politykę dotyczącą ochrony zdrowia psychicznego, w ciągu 15 lat, do 1980 r., liczba hospitalizowanych pacjentów zmniejszyła się do 138 tys., a więc o niemal $60 \%$.

28 Ibidem, s. 255.

29 Ibidem. 
przez psychologów (klinicznych) czy pracowników socjalnych. Wydawało się, że psychodynamika nie musi być uprawiana jedynie przez psychiatrów, a przedstawiciele innych dyscyplin (medycznych i niemedycznych) są w stanie się jej nauczyć i stosować ją z podobnym skutkiem. Innymi słowy, psychiatrzy, stosując strategię ,ucieczki do przodu”, opuścili zbyt zatłoczony rynek usług pychoterapeutycznych i zajęli obszar jeszcze niezagospodarowany, gdyż de facto został on przez nich stworzony. Następne edycje klasyfikacji DSM-IIIR z 1987 r. i DSM-IV z 1994 r. przyczyniły się do utrwalenia zmian w psychiatrii i sposobu definiowania zdrowia psychicznego ${ }^{30}$. Ze względu na fakt, iż nie było możliwe utrzymanie wyłączności na psychoterapię, psychiatrzy podjęli próbę zdefiniowania swojej roli w nowy sposób.

\section{UCIECZKA DO PRZODU: MEDYKALIZACJA PSYCHIATRII}

Marginalizacja psychiatrii jako dyscypliny medycznej, rosnąca niechęć firm ubezpieczeniowych i instytucji rządowych do finansowania długotrwałych psychoterapii, potrzeba skonstruowania nowego sposobu leczenia pacjentów niegdyś trzymanych w szpitalach psychiatrycznych, a obecnie ,przebywających na wolności” oraz rosnąca konkurencja psychologów, doradców i pracowników socjalnych zmusiły psychiatrów do rozważenia zmiany definicji zaburzeń psychicznych.

Włodzimierz Brodniak zwrócił uwagę, że

[...] współczesna psychiatria w przyspieszonym tempie staje się ,psychiatrią biomolekularną”, co ją nobilituje przez włączenie w nurt medycyny molekularnej początku XXI w. Na kongresach i zjazdach naukowych psychiatrzy coraz więcej dyskutują o receptorach, strukturach chemicznych, neurotransmisji i aktywacji kwasów rybonukleinowych, a w codziennej praktyce lekarskiej prawie wyłącznie rozmawia się o lekach i ich wzajemnych interakcjach ${ }^{31}$.

Podłożem teoretycznym rewolucyjnych zmian w psychiatrii była tzw. teoria nierównowagi chemicznej. Pomysł, że depresję powoduje chemiczna nierównowaga $\mathrm{w}$ mózgu, został zaproponowany po raz pierwszy w późnych latach 50 . i wczesnych latach 60. przez kilku różnych naukowców. Początkowo obserwowano pod tym kątem noradrenalinę, ale do połowy lat 60 . zainteresowanie przeniosło się na serotoninę, co w końcu doprowadziło do odkrycia antydepresantów typu SSRI, takich jak Prozac czy Paxil. Największe znaczenie miało odkrycie, że podawanie farmaceutyków działających na poziom serotoniny może w różny sposób wpływać na nastrój. W ten sposób wywnioskowano, że rezultatem zbyt niskiego poziomu serotoniny może być depresja. Uświadomienie sobie, że można wpływać na nastrój przez manipulację chemiczną spowodowało znaczący rozwój

30 Ibidem, s. 264-265.

31 W.A. Brodniak, Czy psychiatrom jest potrzebna socjologia ..., s. 237. 
Pobrane z czasopisma Annales I - Philosophy and Sociology http://philosophia.annales.umcs.pl Data: 26/04/2023 13:39:07

Zmedykalizowana psychiatria jako przykład „geokultury”?...

badań na ten temat i diametralnie zmieniło psychiatrię, spojrzenie na „chorobę psychiczną" oraz branżę farmaceutyczną ${ }^{32}$.

Dla psychiatrów o orientacji biologicznej ta teoria stanowiła bodziec w przekształceniu psychiatrii posługującej się dotąd głównie psychoterapią, której celem było rozwiązywanie problemów życia codziennego, w naukę oferującą pacjentom leczenie chorób o charakterze organicznym. Branża farmaceutyczna także zmieniła swoje oblicze. Firmy farmaceutyczne stały się bardzo zyskownymi przedsięwzięciami komercyjnymi, coraz bardziej opierającymi swoją strategię rozwoju na lekach psychotropowych. W efekcie w $2005 \mathrm{r}$. antydepresanty były najczęściej przepisywanymi lekami w USA, a na ich reklamy przeznaczono 1,5 miliarda dolarów ${ }^{33}$.

Przełom nastąpił w 1980 r., gdy została opublikowana III wersja klasyfikacji zaburzeń psychicznych (DSM-III), która wzorowała się na diagnostycznym modelu biomedycyny. Zmianie uległ charakter zaburzeń psychicznych, odrzucono dotychczasowy paradygmat i przyjęto całkiem nowy system klasyfikacji. Mayes i Horwitz uważają, że te rewolucyjne zmiany nie były ani efektem przyrostu wiedzy, ani przyspieszenia procesu medykalizacji ludzkich problemów. Jest to raczej efekt standaryzacji diagnoz psychiatrycznych, które zostały wymuszone przez narastającą krytykę dyscypliny i jej obniżający się status ${ }^{34}$. Uważają oni, że już wcześniej psychoanaliza zmedykalizowała (spatologizowała) wiele normalnych zachowań ludzkich, poddając je terapii, natomiast w klasyfikacji DSM-III jedynie przekształcono je w konkretne jednostki zaburzeń psychicznych ${ }^{35}$. Jest to niewątpliwie prawda, jednakże wydaje się, że w tym przypadku można też mówić o medykalizacji, ale na innym poziomie. Mianowicie zmedykalizowaniu została poddana psychiatria jako dyscyplina, którą przekształcono niemal całkowicie w neuropsychiatrię, a problemy psychiczne starano się zredukować do „nierównowagi chemicznej mózgu”36.

Prace nad tym dokumentem rozpoczęły się sześć lat wcześniej. Wtedy to Judd Marmor, prezes Amerykańskiego Towarzystwa Psychiatrycznego (APA), poprosił Roberta Spitzera o przewodniczenie grupie mającej za zadanie dokonać uaktualnienia podręcznika zaburzeń psychicznych. DSM-II z 1968 r. oferowało jedynie pobieżne opisy mniej niż 200 jednostek chorobowych i było uważane za nieaktualne i miejscami nieprawidłowe, a także „skażone” psychoanalizą. Wobec rosnących wydatków na leczenie oraz nacisk na ich ograniczanie, psychoanaliza jawiła się jej przeciwnikom jako zbędne obciążenie. W tej sytuacji Melvin Sabshin, ówczesny dyrektor medyczny APA, zwolennik evidence-based psychiatry, zdecydował, że nowe DSM powinno polegać w większym stopniu na danych niż

32 J. Leo, J.R. Lacasse, The Media and the Chemical Imbalance Theory of Depression, „Society" 2007, No. 45, s. 35-36.

33 Ibidem, s. 36.

34 R. Mayes, A.V. Horwitz, op. cit., s. 249.

35 Ibidem, s. 251.

36 J. Leo, J.R. Lacasse, op. cit. 
na opiniach czy ideologii. Dzięki temu dyscyplina miała stać się lepiej przygotowana na zmienną presję ekonomiczną (np. łatwiej będzie rozliczać usługi psychiatrów w ramach amerykańskiego systemu opieki zdrowotnej) ${ }^{37}$.

Powołana do opracowania nowej DSM grupa zadaniowa składała się z psychiatrów, którzy byli zwolennikami tłumaczenia zaburzeń psychicznych przyczynami o charakterze biochemicznym i genetycznym. Byli to naukowcy zaangażowani w medycznie zorientowane badania diagnostyczne, a nie w praktykę kliniczną ${ }^{38}$. Sześcioletni okres prac zespołu, pod przewodnictwem dr. Roberta Spitzera, Christopher Lane opisuje jako nonszalanckie kreowanie nowych zaburzeń i arbitralnego podziału istniejących. „Odkryto” wtedy 112 nowych zaburzeń i ich kategorii ${ }^{39}$. DSM-III i jego następne wersje doprowadzily do zasadniczej zmiany w ocenie zdrowia Amerykanów. Orientacja bazująca na symptomach znacząco wsparła biologiczną wizję zdrowia psychicznego, neuronaukę, badania nad „chemią mózgu” i farmakoterapie, marginalizując dominujące przez dekady podejście psychospołeczne ${ }^{40}$. W ten oto sposób to, co kiedyś było zwykłymi emocjami, stało się stanem medycznym.

Prace psychiatrów przygotowujących te dokumenty Ch. Lane ocenia bardzo surowo. Spitzer utrzymywał, że jego zespół doprowadził do reformy psychiatrii popadającej w coraz większy kryzys, poprawił wiele błędów, odkrył pozostające w ukryciu zaburzenia i uchronił tysiące ludzi przed niepotrzebnym cierpieniem. Jednak według Lane'a zespół troszczył się przede wszystkim o to, by wyeliminować z psychiatrii psychoanalityków i wyznawaną przez nich etiologię zaburzeń psychicznych (a także kojarzące się z psychoanalizą nazewnictwo, m.in. jej fundamentalny termin „neuroza”), wprowadzić definicje zaburzeń swoich sojuszników oraz „zapewnić sobie chwałę" za usunięcie określonego terminu ze słowni$\mathrm{ka}^{41}$. Na podstawie notatek ze spotkań komisji oraz listów przesyłanych do innych psychiatrów Lane ocenił, że członkowie zespołu podejmowali tak ważne decyzje, opierając się na bardzo wątłych podstawach empirycznych, co przyznał nawet jeden z członków zespołu ${ }^{42}$. Lane przytacza wiele wypowiedzi uczestników i obserwatorów procesu tworzenia klasyfikacji, z których wyłania się niepokojący obraz panującego na spotkaniach chaosu oraz forsowania przez członków własnych koncepcji, kierowania się subiektywnymi odczuciami i wrażeniami. Nic więc dziwnego, że część obserwatorów oceniało klasyfikację negatywnie (według nich posiadała rażące braki i była wewnętrznie sprzeczna) $)^{43}$.

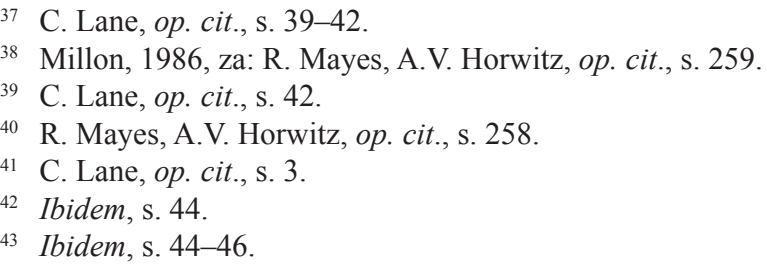


Pobrane z czasopisma Annales I - Philosophy and Sociology http://philosophia.annales.umcs.pl Data: 26/04/2023 13:39:07

Zmedykalizowana psychiatria jako przykład ,geokultury”?...

Efekt był trudny do zaakceptowania przez społeczność psychiatrów z kilku powodów. Po pierwsze, wybrani przez Spitzera współpracownicy (oprócz Theodora Millona) reprezentowali jedną perspektywę teoretyczną, odrzucając Freuda, a preferując Kraepelina - niemieckiego psychiatrę, twórcę klasyfikacji chorób psychicznych, które według niego miały być jedynie podkategorią chorób somatycznych wyodrębnianych na podstawie wnikliwej obserwacji widzialnych symptomów zamiast niepotwierdzonych teorii etiologicznych. Pogląd, że „zaburzenia psychiczne są podklasą zaburzeń medycznych” spotkał się z zarzutem nieuprawnionego redukcjonizmu, dzięki czemu komisja ostatecznie zdefiniowała zaburzenia w mniej kontrowersyjny sposób: ,[...] w DSM-III każde zaburzenie psychiczne jest definiowane jako klinicznie znaczący syndrom behawioralny lub psychologiczny"44. Mimo wszystko po jakimś czasie stało się oczywiste, że prace zespołu nie uwzględniają perspektyw innych szkół psychologicznych (psychoanalitycy mieli poczucie, że komisja zmienia psychiatrię ponad ich głowami). Wiele ustaleń było wynikiem kompromisu, który nie satysfakcjonował nikogo. Po drugie, z powodu dużej złożoności nowych kategorii (konieczność uwzględniania uwag i krytyki psychiatrów o różnych poglądach) istniało duże ryzyko błędu lub zwykłej niespójności, co budziło uzasadniony niepokój, gdyż w przyszłości klasyfikacja miała być podstawą oceny zdrowia psychicznego milionów ludzi.

$\mathrm{W}$ procesie tym uczestniczyły również firmy farmaceutyczne. Isaac Marks, z którym Christopher Lane przeprowadził wywiad, na pytanie o motywacje psychiatrów zajmujących się zmianami nazewnictwa zaburzeń psychicznych, przytoczył historię pewnej konferencji poświęconej zespołowi lęku napadowego. Konferencja ta odbyła się w Bostonie i była sponsorowana przez koncern farmaceutyczny Upjohn. Jak wspomina Marks, jego przedstawiciel całkiem otwarcie przyznał, że „są trzy powody, dla których Upjohn jest zainteresowany tymi diagnozami. Pierwszy z nich to pieniądze. Drugi to pieniądze. A trzeci to pieniądze" ${ }^{45}$. Wiadomym faktem było, iż Upjohn zapłacił za konferencję, ponieważ miał nadzieję, iż obecni na niej eksperci wesprą ich lek Xanax (alprazolam) jako skuteczną terapię zespołu lęku napadowego. Niektórzy z uczestników zaprotestowali, bowiem różnice między epizodami napadów lęku a zespołem lęku napadowego były opisane ogólnikowo. Według Marksa obecność napadu lęku nie jest objawem jakiegokolwiek szczególnego zaburzenia lękowego, z tego względu nie ma powodu do odróżniania zespołu napadu lękowego od zaburzeń niepokoju. Zastrzeżenia te, o których informował na omawianej konferencji, nie tylko nie zostały wzięte pod uwagę, ale także spowodowały, że przestał być zapraszany na kluczowe konferencje dotyczące zespołu lęku napadowego. Marks ocenił, że strategia „osiągania

\footnotetext{
44 R. Mayes, A.V. Horwitz, op. cit., s. 260.

45 C. Lane, op. cit., s. 74.
} 
Pobrane z czasopisma Annales I - Philosophy and Sociology http://philosophia.annales.umcs.pl Data: 26/04/2023 13:39:07

konsensusu przez pomijanie zdania odszczepieńców" stała się wzorcem konstruowania innych zaburzen ${ }^{46}$.

Stworzenie kategorii zespołu napadu lękowego, w ocenie Healy' 'ego ${ }^{47}$, było dla Spitzera i wielu innych psychiatrów okazją do pozbycia się pojęcia „neurozy lękowej" rozumianej nie jako stan medyczny, tylko zaburzenie emocjonalne, co wiąże się z Freudem i psychoanalizą ${ }^{48}$. Podobną genezę można przypisać innemu popularnemu dziś zaburzeniu - zespołowi lęku społecznego, które początkowo określano mianem fobii społecznej. Pojęcie to zaczęło być używane w środowisku brytyjskich psychiatrów w późnych latach 60 . XX w. ${ }^{49}$ Mimo że termin ten ukuł Pierre Janet w 1903 r., dopiero za sprawą pracy Issaca Marksa i Michaela Geldera z 1966 r., będącej przeglądem kilkunastu rodzajów lęku, który zaobserwowali wśród swoich pacjentów, fobia społeczna została zauważona przez środowiska amerykańskich i brytyjskich psychiatrów. Marks i Gelder zaobserwowali, że mała grupa pacjentów (10 mężczyzn i 15 kobiet) przejawia niepokój w różnych sytuacjach społecznych (np. strach przed zarumienieniem się, pójściem na przyjęcie, byciem w centrum uwagi) ${ }^{50}$. „Pacjent, który bał się spacerowania po ulicy z powodu obaw przed wydaniem się śmiesznym w oczach innych ludzi”, miał cierpieć z powodu niepokoju społecznego, a nie agorafobii, którą należy rozumieć jako lęk przed otwartą przestrzenią, tłumem. Lęk społeczny zatem odróżniali oni od agorafobii na podstawie zaistnienia faktu zakłopotania pacjenta. Autorzy pracy przyznawali jednak, że typ niepokoju nie zawsze był oczywisty i łatwy do sprecyzowania oraz że rozróżnienie to jest raczej arbitralne. W klasyfikacji DSM-II wszystkie te objawy przyporządkowywano do kategorii anxiety neurosis, czyli nerwicy lękowej. Marks i Gelder także nie ubolewali nad tym faktem, a nawet twierdzili, iż „spojrzenie behawiorystyczne i psychoanalityczne preferuje jednolite wyjaśnianie fobii, a próby ich podziału okazały się bezowocne”. Kilka lat później, odnosząc się do prac nad DSM-III, Marks stwierdził, że nie ma dowodów na to, że fobia społeczna to odrębne zaburzenie. Mimo to twórcy nowej klasyfikacji uznali pracę Marksa i Geldera za dowód istnienia fobii społecznej, ignorując ich zastrzeżenia (!). Nie powstrzymał ich fakt, iż wyróżniona grupa była proporcjonalnie mała oraz że różne przejawy lęku są ze sobą powiązane i nie ma uzasadnienia dla ich rozdzielania. Jak się okazuje, fobia społeczna - zaburzenie, które zrobiło wielką karierę - „powstała”, mimo że nie istniały żadne badania uzasadniające tę decyzję. Co więcej, do 1980 r., czyli momentu opublikowania DSM-III, powstały inne raporty, w których twierdzono, że nie ma podstaw, by traktować agorafobię

\footnotetext{
46 Ibidem.

47 Za: ibidem, s. 75.

48 Ibidem, s. 57.

49 Healy, 1997, za: ibidem, s. 71.

50 Marks, Gelder, 1966, za: ibidem.
} 
Pobrane z czasopisma Annales I - Philosophy and Sociology http://philosophia.annales.umcs.pl Data: 26/04/2023 13:39:07

Zmedykalizowana psychiatria jako przykład ,geokultury”?...

i niepokój społeczny jako oddzielne syndromy ${ }^{51}$. W ten sposób „rozbito” monolit dotychczasowej kategorii. Przyjęcie i uznanie zespołu napadu lękowego ułatwiło tworzenie następnych zaburzeń lękowych. Do nowej klasyfikacji DSM włączono agorafobię oraz fobię społeczną, ale wiadomo było, że istnieją zaburzenia lękowe, których nie sposób zakwalifikować do wymienionych powyżej jednostek. Większość zaburzeń lękowych przyłączono ostatecznie do nowej kategorii zaburzeń lękowych uogólnionych (generalized anxiety disorder). Ostatecznie neuroza lękowa została zastąpiona siedmioma nowymi zaburzeniami ${ }^{52}$ : agorafobią, zespołem lęku napadowego (panic disorder), zespołem stresu pourazowego (post-traumatic stress disorder), zaburzeniami obsesyjno-kompulsyjnymi (obsessive-compulsive disorder), uogólnionymi zaburzeniami lękowymi (generalized anxiety disorder), fobią prostą (simple phobia) oraz fobią społeczną (social phobia) ${ }^{53}$.

Pomimo tego typu kontrowersji klasyfikacja DSM-III została przyjęta i opublikowana, a entuzjaści przypisali jej sukces potędze wiedzy naukowej. Dokument posiadał według jej zwolenników walor obiektywności jako oparty na faktach i dowodach naukowych, a nie na „teorii” i ,autorytecie charyzmatycznych profesorów". Drugi powód powodzenia, przedstawiany z kolei przez jej krytyków, miał wynikać z wpisywania się w szerszy proces medykalizacji psychiatrii polegający na powiększaniu obszaru zachowań podlegających jurysdykcji psychiatrii zorientowanej biologicznie. Dowodem tej tezy ma być zwiększająca się gwałtownie liczba zaburzeń psychicznych, które są umieszczane w klasyfikacjach (DSM i ICD $)^{54}$. Twierdzono, że pomimo, iż liczba wpisanych do klasyfikacji zaburzeń znacząco się zwiększyła, nie wzrosła ilość zachowań, którymi psychiatria zajmowała się do tej pory. Psychoanaliza zatem już wcześniej zmedykalizowała szereg problemów i psychoanalitycy od dawna przyjmowali pacjentów np. z problemami małżeńskimi, zawiedzionymi ambicjami, nerwowością, niepokojem czy tzw. trudne dzieci. Dlatego Mayes i Horwitz uważają, że w DSM-III dokonano jedynie kategoryzacji szerokiego zakresu patologii w dyskretne jednostki chorobowe, które psychiatria dynamiczna już wcześniej ,zawłaszczyła”. Uznali ponadto, że intencją twórców klasyfikacji było ograniczenie dziedziny psychiatrii do zaburzeń psychicznych, które można wiarygodnie sklasyfikować5 ${ }^{55}$. Wydaje się jednak, że to Christopher Lane jest bliższy prawdzie. Uznał on, że działania komisji miały na celu przyporządkowanie jak największego zakresu ludzkich zachowań do symptomów zaburzenia psychicznego. Mimo że psychiatrzy-psychoanalitycy zajmowali się melancholią, awanturami rodzinnymi, trudnymi dziećmi, niepokojem

51 C. Lane, op. cit., s. 71-72.

52 W DSM IV-TR tych zaburzeń jest już 11 (Diagnostic and Statistical Manual of Mental Disorders, $4^{\text {th }}$ ed., Washington 2000, s. 429-430).

53 C. Lane, op. cit., s. 42.

54 R. Mayes, A.V. Horwitz, op. cit., s. 250-251.

55 Ibidem, s. 251. 
i wieloma innymi problemami życia codziennego, dopiero w DSM-III ustalono jednoznaczne kryteria zaburzeń psychicznych, zobiektywizowano jako choroby różnorodne zachowania ludzi i zakwalifikowano rzesze ludzi do leczenia (głównie farmakologicznego), twierdząc, że zaburzenia te są w gruncie rzeczy chorobami o przynajmniej częściowo biologicznej etiologii.

Ten nowy standaryzowany, biomedyczny system sprzyjał wielu interesom. Psychiatrzy zbliżyli się do upragnionego statusu psychiatrii jako pełnoprawnej subdyscypliny klinicznej, co umożliwiło dokonywanie „pomiarów” chorób psychicznych oraz wyeliminowanie krytyków twierdzących, że chorób psychicznych nie da się mierzyć w obiektywny sposób. Nowy system diagnostyczny legitymizował przekonanie większości klinicystów, że „leczą prawdziwe choroby”, uregulował refundację terapii z pieniędzy płatników usług medycznych i ułatwił ubieganie się o pieniądze publiczne na badania oraz ich przeprowadzanie z metodologicznego punktu widzenia ${ }^{56}$. Oparty na symptomach system, powodując zwielokrotnienie liczby chorych, sprzyjał również rozwojowi organizacji pacjenckich, które stały się bardzo wpływowe, a także był korzystny z punktu widzenia interesów firm farmaceutycznych, bowiem skonstruowane w oparciu o specyficzne symptomy zaburzenia ułatwiają sprzedaż leków ${ }^{57}$. Na nowych definicjach zaburzeń psychicznych skorzystali w pewnym sensie też sami pacjenci, a przynajmniej ci, którzy w zdiagnozowanej zaburzonej tożsamości (np. depresyjnej) dostrzegli m.in. możliwość uzyskania medycznej pomocy, akceptacji przysługującej osobie w roli chorego czy zwolnienia z odpowiedzialności za swoje problemy.

Podsumowując, DSM-III nie tylko zażegnał kryzys psychiatrii, ale i stworzył nowy model choroby psychicznej, który otworzył szerokie możliwości rozwoju dyscypliny. Innymi słowy, klasyfikacja DSM-III skonstruowała powszechnie używany język, którym oprócz psychiatrów posługiwali się psychologowie, pracownicy socjalni, doradcy i sami pacjenci. Za jego pomocą psychiatrzy komunikowali się z przedstawicielami firm ubezpieczeniowych, instytucjami opieki zdrowotnej oraz organami rządu i firmami farmaceutycznymi, które mogłyby wyłożyć miliardy dolarów na badania nad zdrowiem psychicznym i psychofarmakologią. Wyodrębnione w DSM-III zaburzenia psychiczne przyczyniły się do szybkiego wzrostu aktywności badawczej zarówno naukowców, jak i firm farmaceutycznych. W DSM-I i DSM-II nie istniały jasne kategorie diagnostyczne, co uniemożliwiało przeprowadzanie dużych badań klinicznych (FDA - Food and Drug Administration - nie dopuszczała do sprzedaży leków, których działania nie udowodniono w odniesieniu do konkretnych chorób) ${ }^{58}$.

56 Healy, 2000, za: ibidem, s. 262.

57 A.V. Horwitz, J.C. Wakefield, op. cit., s. 560.

58 W latach 80., podczas gdy prezydent Reagan i Kongres USA cięli wydatki na ochronę zdrowia psychicznego i ubezpieczenia społeczne dla osób niepełnosprawnych umysłowo, budżet Naro- 
Konsekwencją stworzenia nowej klasyfikacji zaburzeń psychicznych, rozwijanej w jej następnych edycjach, jest fakt, że aż połowa Amerykanów w pewnym momencie swojego życia spełniała kryteria jakiegoś zaburzenia ${ }^{59}$. Przykładowo David Healy, oceniając zmienione kryteria depresji, stwierdzil, że spowodowało to tysiąckrotne zwiększenie się liczby dotkniętych tym zaburzeniem ${ }^{60}$. Do podobnych wniosków doszedł psycholog kliniczny Oliver James, autor książki Britain on the Couch (w podtytule: Dlaczego jesteśmy bardziej nieszczęśliwi niż w latach 50., mimo że jesteśmy bogatsi: terapia spoleczeństwa z niskim poziomem serotoniny), zauważając, że u około 1/3 dorosłych Brytyjczyków można zdiagnozować jakiś rodzaj zaburzenia psychicznego. Włączając także tych, którzy przejawiają tendencje do przemocy i agresji okazałoby się, że profesjonalnej pomocy potrzebuje około połowa populacji, czyli około 20 milionów ludzi ${ }^{61}$. Rewolucyjne zmiany $\mathrm{w}$ diagnostyce psychiatrycznej spowodowały więc radykalne zmiany w poziomie zapadalności na choroby psychiczne. Zarówno z punktu widzenia historii nauki, jak i analiz epidemiologicznych przełom o takiej skali musi budzić wątpliwości dotyczące tego, czy jego podłożem jest realny postęp naukowy. Wyrazem tego niepokoju był słynny list z 1998 r. zawierający rezygnację z członkostwa w Amerykańskim Towarzystwie Psychiatrycznym (APA) autorstwa Lorena Moshera, byłego szefa Centrum Badań nad Schizofrenią Narodowego Instytutu Zdrowia Psychicznego, do Rodrigo Muñozy, prezesa APA ${ }^{62}$. Rezygnację uzasadnił niemal całkowitym zaprzedaniem psychiatrii koncernom farmaceutycznym, nazywając APA „Amerykańskim Towarzystwem Psychofarmakologicznym". W jego opinii psychiatria nie jest w stanie istnieć bez firm farmaceutycznych sponsorujących ich spotkania, sympozja, warsztaty, bankiety czy wyjazdy szkoleniowe oraz finansowania czasopism naukowych, a psychiatrzy de facto stali się ,,sługami promocji firm farmaceutyczny$\mathrm{ch}^{\text {"63. }}$. Mosher zarzucił także psychiatrom, że dążąc do przekształcenia swojej profe-

dowego Instytutu Zdrowia Psychicznego (NIMH) wzrósł o 84\% do 484 mln dolarów rocznie (Hall, 1993, za: R. Mayes, A.V. Horwitz, op. cit., s. 264). Większość tych pieniędzy została przeznaczona na biologiczne badania podstawowe oraz badania kliniczne skupione na schizofrenii, zaburzeniach nastroju i lękowych.

59 Kessler [et al.], 2005, za: C. Lane, op. cit., s. 3.

60 Healy, 2004, za: C. Lane, op. cit., s. 43.

61 James, 1997, za: M. Fitzpatrick, The Tyranny of Health: Doctors and the Regulation of Lifestyle, London 2001, s. 106.

${ }^{62}$ Cały list znajduje się na stronie www.moshersoteria.com/articles/resignation-from-apa [dostęp: 14.06.2012].

${ }^{63}$ Warto w tym kontekście przywołać znamienną historię, do której odwołuje się Marcia Angell, była redaktor „New England Journal of Medicine”, w artykule Is Academic Medicine for Sale? Opisuje ona, jak duże problemy sprawiło redaktorom czasopisma znalezienie doświadczonego i niezależnego psychiatry, który mógłby napisać artykuł przeglądowy na temat antydepresantów, nie będąc finansowo powiązanym ze sprzedawcami leków (za: R. Moynihan, A. Cassels, Selling Sickness. How Drug Companies are Turning Us All Into Patients, Crow Nest, NSW, Australia 2005, s. 26). 
sji w subdyscyplinę medycyny, ograniczyli swoje intelektualne horyzonty, przyjęli redukcjonistyczny model zdrowia psychicznego i przestali zajmować się pacjentem rozumianym jako umiejscowiona w społecznym kontekście całość, a skupili się na „manipulowaniu neurotransmiterami” i wypisywaniu recept. Autor listu oskarża również swoich kolegów o promowanie używania, a nawet nadużywania, toksycznych substancji chemicznych, które powodują poważne, długoterminowe skutki uboczne. Potępia on także utrzymywanie społeczeństwa w przekonaniu, że zaburzenia psychiczne są chorobami mózgu o podłożu biologicznym (na co nie ma żadnych dowodów). Mosher dodaje, że DSM-IV nie uważa za publikację naukową, lecz polityczną, której celem jest przekonanie innych, że psychiatria to subdyscyplina medyczna. Wspomina również, że teoria chemicznej nierównowagi mózgu to mistyfikacja, a nie „przydatna metafora" ${ }^{64}$.

Podsumowując, wraz z opublikowaniem DSM-III mieliśmy w USA do czynienia ze swoistym ,przewrotem pałacowym”, którego nie można nawet uznać za klasyczną „rewolucję naukową" w kuhnowskim sensie (nie było tam, poprzedzonego okresem paradygmatycznej niestabilności, ścierania się poglądów psychiatrów optujących za psychiatrią psychodynamiczną i „neokrapelinian”). Zmiana była raczej efektem wyciszania głosu oponentów przez wyeliminowanie ich z gremiów decyzyjnych oraz ich ignorowanie (np. wspomniany brak zaproszeń na kongresy). Przewrót ten udał się w dużej części dzięki wydatnej pomocy materialnej korporacji farmaceutycznych, przychylności firm ubezpieczeniowych i administracji publicznej szukającej oszczędności.

\section{KRYTYKA NOWEJ PSYCHIATRII}

Dominacja biochemicznego sposobu wyjaśniania zaburzeń psychicznych w psychiatrii nie jest jednak absolutna. Co więcej, w gruncie rzeczy

[...] w ocenie przyczyn i uwarunkowań zaburzeń psychicznych stało się już od dawna w nauce kanonem podkreślanie, że są one złożone, wieloczynnikowe i w znacznym zakresie dyskusyjne, a w przypadku wielu chorób psychicznych często nieznane. [...] Jest truizmem twierdzenie, że opisując etiopatogenezę zaburzeń psychicznych podkreśla się różną rolę i wzajemnie sprzężony wpływ na ich wystąpienie trzech rodzajów czynników: biologicznych, psychologicznych i społeczno-kulturowych ${ }^{65}$.

${ }^{64}$ Leo i Lacasse (op. cit., s. 44) zwracają uwagę, że od kiedy na rynku pojawily się nowe antydepresanty typu SSRI, psychiatria aktywnie tę teorię wspierała, a wraz z pojawianiem się nowych dowodów na jej fałszywość, ani jej nie zaczęła bronić, ani nie wyjaśniła, na czym polega jej problematyczność oraz manipulacja w reklamach farmaceutyków, w których przekonuje się zwykłych ludzi, że teoria nierównowagi chemicznej to fakt.

${ }_{65}$ W.A. Brodniak, Społeczno-kulturowe uwarunkowania zaburzeń psychicznych. Próba syntezy, [w:] Zdrowie, choroba, społeczeństwo. Studia z socjologii medycyny, red. W. Piątkowski, Lublin 2004, s. 45. 
Pobrane z czasopisma Annales I - Philosophy and Sociology http://philosophia.annales.umcs.pl Data: 26/04/2023 13:39:07

Zmedykalizowana psychiatria jako przykład ,geokultury”?...

Zrozumiałe, że w przypadku tak złożonej etiologii zaburzeń psychicznych istnieje bardzo dużo koncepcji etiologicznych. Szereg badaczy w łonie tej dyscypliny przyjmuje więc krytyczną postawę wobec promowanej obecnie nozologii i etiologii zaburzeń psychicznych. Jeden z nich, profesor psychologii i neurologii Eliot Valenstein, uważa tłumaczenie występowania zaburzeń niepokoju wyłącznie czynnikami biologicznymi za nieuprawniony redukcjonizm. W książce Blaming the Brain: the Truth about Drugs and Mental Health pisze, iż fakt, że pewne cechy powtarzają się w rodzinach, nie jest dowodem ich genetycznej etiologii, bowiem w takim wypadku takie „,echy”, jak ubóstwo, którego dziedziczność jest empirycznie potwierdzona, także należałoby uznać za genetycznie uwarunkowane. Christopher Lane przytacza szereg innych argumentów Valensteina: stan psychiczny i doświadczenia jednostki mogą modyfikować funkcjonowanie mózgu tak samo, jak mózg wpływa na ludzkie zachowania (mimo to neuropsychiatria ujmuje biochemiczne procesy mózgu jedynie jako przyczynę, a zachowanie jednostki jako skutek); leki używane do terapii zaburzeń psychicznych mogą powodować długotrwałe biochemiczne, a nawet strukturalne zmiany (w mózgu), które w przeszłości były uznawane za przyczynę zaburzenia, ale faktycznie są skutkiem leczenia; ustalanie przyczyny choroby na podstawie efektywności leczenia może być rażąco zwodnicze i okazać się nieścisłe; zakładanie, że zaburzenie ma biologiczne przyczyny, nie musi znaczyć, że biologiczne leczenie będzie najbardziej efektywne - stan może mieć biologiczne pochodzenie, ale może być poddawany terapii psychologicznej i - co więcej - odwrotność może być równie prawdziwa ${ }^{66}$. Leo i Lacasse zauważyli, że powodem krytykowanego przez nich redukcjonizmu jest mieszanie dwóch pojęć: korelacji i przyczyny. Mimo że różnica między tymi terminami wydaje się mała, ich definicje mają ogromne znaczenie w dyskusji na temat relacji pomiędzy psychologią i biologią. Dowody potwierdzające istnienie korelacji między stresorami środowiskowymi a zmianami w mózgu na poziomie biologicznym nie świadczą o tym, że choroby psychiczne są ,powodowane” jakimiś deficytami biologicznymi. Autorzy ci zwracają uwagę na fakt, iż publikuje się coraz więcej badań wykazujących odwrotną zależność, tzn. wyników potwierdzających istnienie biologicznych zmian w mózgu na skutek bodźców środowiskowych. Podaje się w tym kontekście przykład hipokampu (części mózgu odpowiadającej głównie za uczenie się i pamięć), który pod wpływem silnego stresu może zostać uszkodzony. Potwierdzeniem reaktywności mózgu na czynniki zewnętrzne jest także metaanaliza, z której wynika, że 69\% pacjentek, u których zdiagnozowano psychozę, zgłaszało doświadczanie przemocy fizycznej i psychicznej. Loren Mosher i Mary Boyle uznają właśnie czynniki społeczne i środowiskowe za najbardziej znaczące w występowaniu zaburzeń psychicznych - jeśli z badań wynika, że przynajmniej 50-60\% kobiet przyjętych do szpitali psychiatrycznych, bez

${ }^{66}$ Za: C. Lane, op. cit., s. 19-20. 
względu na zdiagnozowane zaburzenie, doświadczało psychicznej lub fizycznej przemocy, to czy nie jest uzasadnione, by tego typu doświadczenia wiązać z chorobą? ${ }^{67}$ Bardzo możliwe, że u kobiet tych odkryto by nierównowagę chemiczną, ale wobec powyższych danych o wiele mniej przekonująco wypada twierdzenie, że zaburzenia psychiczne są skutkiem genetycznych predyspozycji ${ }^{68}$.

Odnosząc się do teorii nierównowagi chemicznej mózgu, warto zauważyć, że środki używane do jej niwelowania traktuje się jako „leki”, natomiast substancje stosowane w celu „rozluźnienia” są zazwyczaj uważane za narkotyki. Rodzi się pytanie, czy granica między antydepresantem a narkotykiem jest dostatecznie wyraźna? Istnieje szereg substancji psychoaktywnych - niektóre są legalne (alkohol, Valium), inne nie (marihuana, heroina) - które ludzie stosują, by złagodzić skutki niepokoju czy depresji. Utrzymuje się, że skoro antydepresanty SSRI oddziałują na poziom serotoniny, to ich działanie musi być wynikiem istnienia u niektórych ludzi nieodpowiedniego poziomu serotoniny w mózgu. Innymi słowy, utożsamia się zwiększanie poziomu serotoniny z przywracaniem jakiegoś idealnego, zdrowego poziomu tej substancji. Wiadomo jednak, że narkotyk o nazwie LSD także zwiększa poziom serotoniny, przy czym nikt nie twierdzi, że działa on jedynie na jednostki, które cierpią z powodu nierównowagi chemicznej. Można zadać pytanie: dlaczego? Leo i Lacasse dają odpowiedź: bez teorii o nierównowadze chemicznej mózgu antydepresanty SSRI nie mogą być traktowane jako leki przywracające pacjenta do stanu normalności i stają się jedynie następną grupą substancji psychoaktywnych (tak jak LSD). Efektywność tych leków stanowi jeden z głównych argumentów istnienia realnych chorób psychicznych i z tego względu marketingowcy firm farmaceutycznych tak uparcie propagują omawianą teorię. Dzięki niej koncerny nie sprzedają już uśmierzających cierpienie substancji psychoaktywnych, ale autentyczne leki służące eliminacji przyczyn prawdziwych (biologicznych) chorób ${ }^{69}$.

Mimo poniesienia znacznych kosztów mających na celu dostarczenie naukowego potwierdzenia, istnienie chemicznej nierównowagi nie zostało do tej pory udowodnione. Co więcej, skuteczność w leczeniu depresji antydepresantami SSRI, która stanowiła główny argument jej zwolenników, coraz częściej jest podważana. W 2002 r. Irving Kirsch ze współpracownikami uzyskali dostęp do wszystkich testów klinicznych antydepresantów przedłożonych FDA przez firmy farmaceutyczne, niezbędnych w procesie zatwierdzania leków. Kiedy

${ }^{67}$ L.R. Mosher, M. Boyle, Rethinking in Mental Health Industry, "Ethical Human Psychology and Psychiatry" 2004, Vol. 6, No. 3, s. 237-238.

${ }_{68}$ Co ciekawe, nie tylko stresory psychologiczne mogą być przyczyną zaburzeń psychicznych. Leo i Lacasse (op. cit., s. 36) przytaczają także badania byłych graczy NFL (liga futbolu amerykańskiego) pokazujące, że istnieje dodatnia korelacja pomiędzy liczbą kontuzji a prawdopodobieństwem zachorowania na depresję w późniejszych latach.

69 Ibidem, s. 37-38. 
Pobrane z czasopisma Annales I - Philosophy and Sociology http://philosophia.annales.umcs.pl Data: 26/04/2023 13:39:07

Zmedykalizowana psychiatria jako przykład ,geokultury”?...

opublikowane i nieopublikowane wyniki zostały przeanalizowane łącznie, okazało się, że w grupie otrzymującej placebo efekt terapeutyczny zaobserwowano w $80 \%$ przypadków, a w przypadku np. Prozacu $-89 \%$. Innymi słowy, lek ten jest skuteczny w przypadku jednego lub dwóch z 10 pacjentów ${ }^{70}$. Leo i Lacasse zwracają zatem uwagę na niepokojący fakt, iż $80 \%$ lub $90 \%$ pacjentów przyjmuje uzależniające i powodujące wiele skutków ubocznych leki zupełnie niepotrzebnie. Te zarzuty powodują, że w zasadzie nie ma badaczy, którzy otwarcie i z pełnym zaangażowaniem stanęliby w obronie teorii chemicznej nierównowagi mózgu.

Podsumowując, krytycy redukcjonizmu biologicznego w psychiatrii uświadamiają kruchość i niestabilność założeń teoretycznych oraz niewielką liczbę twardych dowodów dla biochemicznej teorii zaburzeń psychicznych. Mimo to paradygmat biologiczny w psychiatrii wydaje się bardziej obecny niż koncepcje psychodynamiczne i humanistyczne. Paradygmat ten, mimo braku naukowych dowodów, dominuje w praktyce terapeutycznej, co sugeruje istnienie innych, pozanaukowych przesłanek jego stosowania. Postawa radykalnie biologizujących psychiatrów jest albo oparta na myśleniu życzeniowym („,mamy rację, choć nie mamy jeszcze dowodu, ale to tylko kwestia czasu"), albo świadczy o nieszczerości wobec pacjentów i opinii publicznej oraz kierowaniu się chęcią zachowania lukratywnego dla dyscypliny i pojedynczych psychiatrów status quo.

\section{PRZYJAZNE ŚRODOWISKO: NEOLIBERALIZM}

Warto podkreślić, że rewolucja w psychiatrii zbiegła się w czasie z innym ważnym przewrotem. W latach 80 . w krajach anglosaskich tryumfy święcił liberalizm gospodarczy. Objęcie władzy przez wyznawców wolnego rynku, Reagana i Thatcher, stanowiło motor „rewolucji konserwatywnej”, która zaczęła wpływać na politykę i życie intelektualne w innych państwach rozwiniętych. Pogarszająca się sytuacja ekonomiczna była okazją do ograniczenia przez konserwatystów interwencjonizmu państwowego, cięć w budżetach, prywatyzacji państwowych sektorów gospodarki ${ }^{71}$. Teoretyczną podstawą tych polityczno-ekonomicznych praktyk stała się względnie zapomniana doktryna „neoliberalizmu”, która zakłada, że ludzkiemu dobrobytowi najlepiej służą uwolnienie przedsiębiorczości, mocne prawa własności prywatnej, możliwie wolne rynki i handel, a państwo ma jedynie zapewnić bezpieczeństwo praw własności i wolnych rynków oraz tworzyć „klimat” do kreowania rynków tam, gdzie jeszcze ich nie ma (np. woda,

70 I. Kirsch [et al.], Initial Severity and Antidepressant Benefits: a Meta-Analysis of Data Submitted to the Food and Drug Administration, "PLoS Medicine" 2008, No. 5(2).

71 B. Jung, Kapitalizm postmodernistyczny, „Ekonomista” 1997, nr 5, s. 3. 
Pobrane z czasopisma Annales I - Philosophy and Sociology http://philosophia.annales.umcs.pl Data: 26/04/2023 13:39:07

szkolnictwo, opieka zdrowotna) ${ }^{72}$. Co oczywiste, wprowadzanie takiej doktryny wiąże się z „twórczą destrukcją" nie tylko

[...] uprzednio istniejących ram instytucjonalnych i układów sił (często rzucając przy tym wyzwanie tradycyjnym formom suwerenności państwowej), ale również systemu podziału pracy, stosunków społecznych, urządzeń socjalnych, poziomów zaawansowania technicznego, sposobów życia i myślenia, zachowań reprodukcyjnych, związków z ziemią i emocjonalnych przyzwyczajeńn ${ }^{73}$.

W obszarze nauki i medycyny najważniejszymi przejawami „neoliberalizmu" były probiznesowe zmiany legislacyjne. Na początku $1980 \mathrm{r}$. Kongres USA przyjął serię praw, których intencją było usprawnienie transferu wiedzy do biznesu uzyskanej z badań finansowanych z pieniędzy publicznych. Miały także służyć poprawie pozycji na świecie amerykańskich firm high-tech. Jedna z ustaw, Bayh-Dole Act (od nazwisk autorów Bricha Bayha i Roberta Dole'a), umożliwiała uniwersytetom i małym przedsiębiorstwom patentowanie odkryć pochodzących z badań finansowanych z pieniędzy publicznych (przez Państwowe Instytuty Zdrowia) i udzielanie wyłącznych licencji firmom na korzystanie z nich. Było to ogromnym bodźcem dla rozwoju firm biotechnologicznych i farmaceutycznych ${ }^{74}$. Firmy biotechnologiczne, zakładane niejednokrotnie przez naukowców zatrudnionych na uniwersytetach i prowadzących badania za pieniądze publiczne, realizują początkowe fazy opracowywania leku z nadzieją na lukratywny interes z firmą farmaceutyczną, natomiast te drugie mogą coraz bardziej opierać się na wynikach zewnętrznych badań. Jak pisze Angell, ,,jedna trzecia nowych leków wielkich firm pochodzi z zewnątrz i te są przeważnie najbardziej innowacyjne"75. Komercjalizacja zasad upowszechniania wyników badań naukowych spowodowała również zmiany mentalne w środowisku naukowców. Poczucie misji związanej z pracą naukową rozumianą jako działalność dla dobra społecznego, wcześniej silne wśród badaczy i intelektualistów, zaczęło zanikać. Zmienił się również etos uczelni medycznych i szpitali klinicznych, które przekształciły się w przedsiębiorstwa czerpiące zyski z efektów badań sponsorowanych przez podatnika. W takiej atmosferze naukowcy stawali się w coraz większym stopniu wspólnikami przemysłu, przyjmując $\mathrm{w}$ odniesieniu do prowadzenia badań perspektywę przedsiębiorcy. Skutkiem tego było również zmniejszenie zainteresowania badaczy (a także finansowania z publicznych pieniędzy) badaniami podstawowymi, których efekty są trudniejsze do skomercjalizowania ${ }^{76}$.

72 D. Harvey, Neoliberalizm: historia katastrofy, Warszawa 2008, s. 9.

73 Ibidem, s. 10.

74 W.H. Schacht, The Bayh-Dole Act: Selected Issues in Patent. Policy and the Commercialization of Technology, "CRS Report of Congress" 2012, March 16, RL32076, s. 8-9.

75 M. Angell, Prawda o firmach farmaceutycznych, „Aptekarz” 2005, nr 13 (suplement), s. $11-12$.

76 Ibidem, s. 12. 
Zacieśnianie się relacji pomiędzy przemysłem a nauką przebiegało nie tylko z powodu powyższych ułatwień, ale było też efektem coraz gorszego finansowania nauki i medycyny z publicznych środków. Amerykański Balance Budget Act z 1997 r., zmniejszając budżety szpitali i jednostek zajmujących się edukacją medyczną, spowodował, że musiały one wypełnić swoje dziury budżetowe, przyjmując zlecenia korporacji farmaceutycznych (testy kliniczne leków). W rezultacie jednostki naukowe i pracujący w nich naukowcy, których jednym z celów jest prowadzenie badań podstawowych, stają się coraz bardziej uzależnieni od przemysłu biotechnologicznego ${ }^{77}$. Tym samym jeśli naukowcy chcą liczyć na pieniądze, rozwój naukowy i prestiż, muszą pogodzić się z faktem, iż coraz częściej cele badawcze będą im wyznaczać firmy farmaceutyczne liczące na szybkie zyski.

Wybuch „neoliberalizmu” i globalizacja, która dla handlu zniosła niemal wszystkie granice, niezmiernie zwiększyły znaczenie i bogactwo korporacji. Do najpotężniejszych należą firmy farmaceutyczne. Bardzo duża część tych największych pochodzi ze Stanów Zjednoczonych (a niemal wszystkie z krajów wysoko rozwiniętych). Bogactwo korporacji i znikające bariery powodują, że to rynki i transnarodowy kapitał w coraz większym stopniu mają wpływ na życie milionów ludzi na całym świecie. Rozwinięty przemysł farmaceutyczny może pochwalić się globalnym zasięgiem (nie tylko w sensie geograficznym) - jest w stanie dystrybuować swoje produkty każdemu: indywidualnym klientom i masowym odbiorcom (rządom państw, publicznym systemom ochrony zdrowia, prywatnym szpitalom, firmom ubezpieczeniowym). Ma również możliwość „zagłuszania” głosu oponentów i promowania przez korporacyjny PR swego „dorobku” jako prawomocnej wiedzy. Koncerny dysponują także środkami, by ingerować w procesy legislacyjne, wpływać na instytucje kontrolne (EMA, FDA, WHO) ${ }^{78}$, manipulować mediami i opinią publiczną ${ }^{79}$, korumpować lekarzy, a nawet kształtować wiedzę medyczną (zob. medyczny ghostwriting) ${ }^{80}$.

Interesy korporacji są zarówno celem, jak i środkiem dla kapitalistycznego systemu-świata. Z tego względu oczywiste jest, że stworzenie im przyjaznego

77 A.E. Clarke [et al.], Biomedicalization: Technoscientific Transormations of Health, Illness, and U.S. Biomedicine, "American Sociological Review" 2003, No. 68, s. 169.

78 B. Goldacre, Zle leki. Jak firmy farmacentyczne wprowadzaja $w$ bład lekarzy i krzywdza pacjentów, Katowice 2013; P. Polak, Nowe formy korupcji. Analiza socjologiczna sektora farmaceutycznego w Polsce, Kraków 2011.

79 K. Applbaum, Pharmaceutical Marketing and the Invention of the Medical Consumer, "PloS Medicine" 2006, No. 3(4); R. Moynihan, I. Heath, D. Henry, Selling Sickness: the Pharmaceutical Industry and Disease Mongering, "British Medical Journal" 2002, No. 324(7342).

80 A.J. Fugh-Berman, The Haunting of Medical Journals: How Ghostwriting Sold "HRT", "PloS Medicine" 2010, No. 7(9); A. Górski, S. Letkiewicz, "Medical Writing" and Ghostwriting as Ethical Challenges in Medical Communication, "Transplantation Proceedings" 2010, No. 42(8); R. Smith, Medical Journals are an Extension of the Marketing Arm of Pharmaceutical Companies, "PLoS Medicine" 2005, No. 2(5). 
i zapewniającego wzrost „środowiska życia” jest z punktu widzenia systemu bardzo pożądane. W sektorze farmaceutycznym wzrost zysków korporacji zapewnia postępująca medykalizacja. Zarysowana wcześniej rewolucja w psychiatrii stanowiła przykład tego procesu. Jeśli przyjmiemy perspektywę teoretyczną i aparat pojęciowy Immanuela Wallersteina, można sformułować twierdzenie, że współczesna amerykańska psychiatria, która kształtowała się w warunkach malejących nakładów państwa na ochronę zdrowia i rosnącej roli firm farmaceutycznych, pełni funkcję Wallersteinowskiej ,geokultury”. Jej celem jest promowanie zmedykalizowanej koncepcji zaburzeń psychicznych, dzięki której legitymizuje się stosowanie farmakoterapii. Rozprzestrzeniająca się poza USA klasyfikacja DSM stanowi nośnik zmedykalizowanej koncepcji zaburzeń psychicznych, jakże użytecznej dla globalnego rynku leków. Współczesna klasyfikacja, wraz z leżącą u jej podłoża koncepcją biochemicznej etiologii zaburzeń psychicznych, zapewnia zbyt na drogie, opatentowane produkty na obszarach semiperyferyjnych i peryferyjnych, marginalizując jednocześnie psychoterapie, które są dobrem niestanowiącym własności intelektualnej kapitału pochodzącego z obszarów centralnych, przez co ich wartość marketingowa jest mała. Korzystając z terminologii Wallersteina, można powiedzieć, że firmy farmaceutyczne uczyniły z patentowanych leków ,produkty wiodące” o charakterze centralnym - względnie zmonopolizowane, a przez to przynoszące wysokie zyski, i wywierające silny wpływ na gospodarkę ${ }^{81}$. Psychiatrzy z krajów (pół)peryferyjnych, jako przedstawiciele elit peryferyjnych, poddawani są presji wchodzących na lokalne rynki firm farmaceutycznych i dostosowują się do amerykańskiego sposobu postrzegania zaburzeń psychicznych. Pełnią tym samym rolę tłumacza kultury centrum, pośrednika między centrum a peryferyjnym, własnym społeczeństwem. Dzięki zinternalizowaniu nowych zasad elity kompradorskie mogą uczestniczyć w nowej grze i korzystać z zysków.

$\mathrm{Na}$ koniec warto jeszcze dodać, że funkcja zmedykalizowanej psychiatrii (i medykalizacji w ogóle) nie służy jedynie firmom farmaceutycznym. Socjolog medycyny Kirstin Barker stwierdza, że ekonomiczne zyski z medykalizacji to nie tylko bezpośrednie profity osiągane przez przemysł medyczny. Medykalizacja, kładąc nacisk na indywidualne rozwiązania różnych problemów dotyczących ludzkiego życia, zaniedbuje czynniki społeczne i ekonomiczne, a więc dokonuje depolityzacji problemów społecznych, odwraca od nich uwagę, zabezpieczając w ten sposób swoje interesy ekonomiczne i, szerzej, interesy sił globalnego kapitalizmu. Dla Barker medykalizacja pełni funkcję strażnika ekonomicznego status quo, stano-

81 I. Wallerstein, op. cit., s. 140. Same leki nie muszą być fizycznie produkowane w krajach z centrum - mogą być taniej wywarzane przez fabryki na peryferiach. Korporacje czerpią zyski $\mathrm{z}$ wiedzy, którą same przecież wytwarzają przy pomocy psychiatrii. 
wiąc swoiste nowe „opium dla ludu”"82. Jeśli zatem spojrzymy na Stany Zjednoczone jako centrum obecnego systemu ekonomicznego (centrum Wallersteinowskiego systemu-świata), to zrozumiały staje się fakt największego zaawansowania procesu medykalizacji właśnie w tym kraju. Innymi słowy, medykalizacja rozprzestrzenia się na świecie wraz z globalnym kapitalizmem transnarodowych korporacji pochodzącym z USA. Oczywiście, na kształt i tempo medykalizacji wpływają także inne istotne czynniki (np. kulturowo uwarunkowana skłonność do chodzenia do lekarza bądź korzystanie z „ludowych” leków czy specyficzne dla danego kraju mechanizmy refundacji leków i usług medycznych), niemniej wydaje się, że nie decydują one o globalnym trendzie (nie są w stanie go odwrócić), przesądzają jedynie o regionalnej specyfice, do której korporacje potrafią się dostosować.

\section{BIBLIOGRAFIA}

Angell M., Prawda o firmach farmaceutycznych, „Aptekarz” 2005, nr 13 (suplement).

Applbaum K., Pharmaceutical Marketing and the Invention of the Medical Consumer, "PloS Medicine" 2006, No. 3(4).

Baer H.A., Singer M., Susser I., Medical Anthropology and the World System, $2^{\text {nd }}$ ed., Westport 2003.

Barbaro B. de, Tożsamość psychiatrii?, „Postępy Psychiatrii i Neurologii” 2010, Vol. 19, nr 4.

Brodniak W.A., Czy psychiatrom jest potrzebna socjologia zaburzeń psychicznych?, [w:] W strone socjologii zdrowia, red. W. Piątkowski, A. Titkow, Lublin 2002.

Brodniak W.A., Społeczno-kulturowe uwarunkowania zaburzeń psychicznych. Próba syntezy, [w:] Zdrowie, choroba, społeczeństwo. Studia z socjologii medycyny, red. W. Piątkowski, Lublin 2004.

Clarke A.E., Mamo L., Fishman J.R., Shim J.K., Fosket J.R., Biomedicalization: Technoscientific Transormations of Health, Illness, and U.S. Biomedicine, "American Sociological Review" 2003, No. 68.

Diagnostic and Statistical Manual of Mental Disorders, $3^{\text {rd }}$ ed., Washington 1980.

Diagnostic and Statistical Manual of Mental Disorders, $4^{\text {th }}$ ed., Washington 2000.

Fitzpatrick M., The Tyranny of Health: Doctors and the Regulation of Lifestyle, London 2001.

Fugh-Berman A.J., The Haunting of Medical Journals: How Ghostwriting Sold "HRT", "PloS Medicine" 2010, No. 7(9).

Ghaemi N., Letter to a Foreign Psychiatrist, "Psychiatric Times" 2013, www.psychiatrictimes.com/ letter-foreign-psychiatrist [dostęp: 05.12.2013].

Goldacre B., Złe leki. Jak firmy farmaceutyczne wprowadzają w błąd lekarzy i krzywdza pacjentów, Katowice 2013.

Górski A., Letkiewicz S., "Medical Writing” and Ghostwriting as Ethical Challenges in Medical Communication, "Transplantation Proceedings" 2010, No. 42(8).

Harvey D., Neoliberalizm: historia katastrofy, Warszawa 2008.

Heitzman J., Łoza B., Kosmowski W., Klasyfikacja zaburzeń psychicznych-koncepcyjne założenia ICD-11, „Psychiatria Polska” 2011, Vol. XLV, nr 6.

82 A. Maturo, Discussion. Medicalization, Multiplication of Diseases and Human Enhancement. Round table with Kristin Barker, Ivo Quaranta, Martijntje Smits and Louis Francois Vedelago, "Salute e Società" 2009, Vol. VIII, No. 2, s. 101-102. 
Horwitz A.V., Wakefield J.C., The Medicalization of Sadness: How Psychiatry Transformed a Natural Emotion into a Mental Disorder, "Salute e Società" 2009, Vol. VIII, No. 2.

Hunt C.W., Migrant Labor and Sexually Trasnmitted Disease: AIDS in Africa, "Journal of Health and Social Behavior" 1989, Vol. 30, No. 4, DOI: http://dx.doi.org/10.2307/2136985.

Hyde M., Rosie A., World Systems Theory and the Epidemiological Transition, [w:] Contemporary Theorists for Medical Sociology, ed. G. Scambler, Abington, Oxon 2012.

Jung B., Kapitalizm postmodernistyczny, „Ekonomista” 1997, nr 5.

Kirsch I., Deacon B.J., Huedo-Medina T.B., Scoboria A., Moore T.J. [et al.], Initial Severity and Antidepressant Benefits: a Meta-Analysis of Data Submitted to the Food and Drug Administration, "PLoS Medicine" 2008, No. 5(2).

Lane C., Shyness. How Normal Behavior Became a Sickness, New Haven \& London 2007.

Leo J., Lacasse J.R., The Media and the Chemical Imbalance Theory of Depression, "Society" 2007, No. 45.

Letter of Resignation from the American Psychiatric Association, www.moshersoteria.com/articles/ resignation-from-apa [dostęp: 14.06.2012].

Maturo A., Discussion. Medicalization, Multiplication of Diseases and Human Enhancement. Round table with Kristin Barker, Ivo Quaranta, Martijntje Smits and Louis Francois Vedelago, "Salute e Società" 2009, Vol. VIII, No. 2.

Mayes R., Horwitz A.V., DSM-III and the Revolution in the Classification of Mental Illness, ,Journal of the History of the Behavioral Sciences" 2005, Vol. 41(3), DOI: http://dx.doi.org/10.1002/jhbs.20103.

Mohyuddin A., Mamonah A., Naveed J., Ahmad D., World System Analysis of Biomedical Hegemony, "Advances in Anthropology" 2014, No. 4.

Mosher L.R., Boyle M., Rethinking in Mental Health Industry, "Ethical Human Psychology and Psychiatry" 2004, Vol. 6, No. 3.

Moynihan R., Cassels A., Selling Sickness. How Drug Companies are Turning Us All Into Patients, Crow Nest, NSW, Australia 2005.

Moynihan R., Heath I., Henry D., Selling Sickness: the Pharmaceutical Industry and Disease Mongering, "British Medical Journal" 2002, No. 324(7342).

Nowakowski M., Krytycy współczesnej medycyny. Proces medykalizacji w perspektywie nauk spotecznych, [w:] Lekarz - historia i wyzwania zawodu, red. E. Anczyk, Sosnowiec 2010.

Polak P., Nowe formy korupcji. Analiza socjologiczna sektora farmaceutycznego w Polsce, Kraków 2011.

Rosenhan D.L., Being Sane in Insane Places, "Science" 1973, No. 179(4070).

Schacht W.H., The Bayh-Dole Act: Selected Issues in Patent. Policy and the Commercialization of Technology, "CRS Report of Congress" 2012, March 16, RL32076.

Shorter E., Before Prozac: the Troubled History of Mood Disorders in Psychiatry, New York 2009.

Smith R., Medical Journals are an Extension of the Marketing Arm of Pharmaceutical Companies, "PLoS Medicine" 2005, No. 2(5).

Wallerstein I., Analiza systemów-światów. Wprowadzenie, Warszawa 2007.

\section{SUMMARY}

In the $6^{\text {th }}$ and the $7^{\text {th }}$ decade of the $20^{\text {th }}$ century, American psychiatry, torn by internal disputes and external criticism, was experiencing a deep crisis. As a result of the revolutionary paradigm shift (the abandonment of psychoanalysis and psychotherapy for the biological concept of mental disorders and pharmacotherapy) psychiatry managed to turn into a generously financed from public and corporate resources, dynamically developing medical discipline whose subject of study are diseases of the brain.

Moreover, the new medicalised psychiatry spread all over the world. The success of American psychiatry and its "flagship" achievement - the classification of mental disorders (DSM), is the re- 
Pobrane z czasopisma Annales I - Philosophy and Sociology http://philosophia.annales.umcs.pl Data: 26/04/2023 13:39:07

Zmedykalizowana psychiatria jako przykład „geokultury”?...

sult of meeting the expectations of neoliberal, globalized economy and greater compatibility with the interests of pharmaceutical companies (for which psychiatric drugs are one of the main sources of profits). Modern psychiatry and DSM will also be shown as a part of Wallerstein's "geoculture" that supports and legitimizes the domination of capital from the center of the capitalist world-system. Therefore, the aim of this article is to present the global dominance of an American psychiatry as a synergistic effect of cooperation between American psychiatrists and pharmaceutical companies, which has led to export of the American nosology of mental disorders.

Keywords: psychiatry; medicalization; Wallerstein; geoculture 